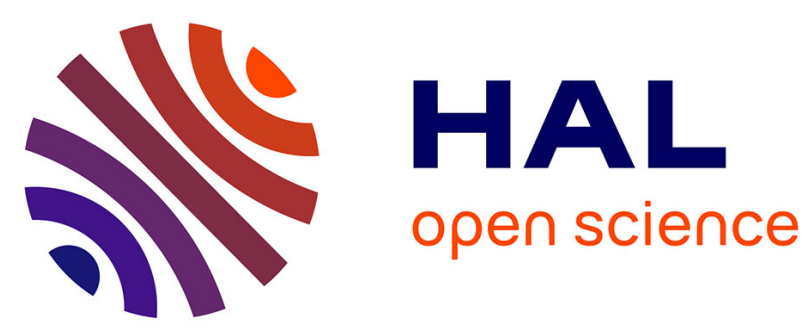

\title{
A THIN SUPERCONDUCTING SOLENOID WOUND WITH THE INTERNAL WINDING METHOD FOR COLLIDING BEAM EXPERIMENTS
}

A. Yamamoto, H. Inoue, H. Hirabayashi

\section{- To cite this version:}

A. Yamamoto, H. Inoue, H. Hirabayashi. A THIN SUPERCONDUCTING SOLENOID WOUND WITH THE INTERNAL WINDING METHOD FOR COLLIDING BEAM EXPERIMENTS. Journal de Physique Colloques, 1984, 45 (C1), pp.C1-337-C1-340. 10.1051/jphyscol:1984169 . jpa-00223725

HAL Id: jpa-00223725

https://hal.science/jpa-00223725

Submitted on 1 Jan 1984

HAL is a multi-disciplinary open access archive for the deposit and dissemination of scientific research documents, whether they are published or not. The documents may come from teaching and research institutions in France or abroad, or from public or private research centers.
L'archive ouverte pluridisciplinaire HAL, est destinée au dépôt et à la diffusion de documents scientifiques de niveau recherche, publiés ou non, émanant des établissements d'enseignement et de recherche français ou étrangers, des laboratoires publics ou privés. 


\section{A THIN SUPERCONDUCTING SOLENOID WOUND WITH THE INTERNAL WINDING METHOD FOR COLLIDING BEAM EXPERIMENTS}

A. Yamamoto, H. Inoue and H. Hirabayashi

KEK, National Laboratory for High Energy Physics, Oho-machi, Tsukuba-gun, Ibaraki-ken, 305, Japan

Résumé - On présente une nouvelle méthode de fabrication d'un grand solénoïde mince. Ce solénoỉde utilise un supraconducteur NbTi/Cu/Al bobiné sur la face interne d'un cylindre d'aluminium. La fabrication du solénoide par cette méthode est en cours.

Abstract - A new fabrication method of a thin and large solenoids is presented. The solenoid is wound with $\mathrm{NbTi} / \mathrm{Cu} / \mathrm{Al}$ superconductor, which is wound on the inner surface of an aluminum cylinder. The fabrication of the solenoid is in progress with this method.

\section{I - INTRODUCTION}

A thin superconducting solenoid with the size of $2.9 \mathrm{mr} \times 5.1 \mathrm{~m}$ and with the field of 1.2 Tesla will be used in the colliding beam detector "TOPAZ" for TRISTAN project at KEK (Fig. 1)/1/. A new technique has been developed in realizing the large thin solenoid. It is called "internal winding" method. In conventional way $12,3,4 /$, a coil is wound on the surface of cylindrical bobbin with sufficient tension. The bobbin is very useful to wind the coil, but does very little to reinforce the coil against the electromagnetic force which acts outward. Thus a banding on the outer surface of the coil is necessary to withstand this strong force. The new internal winding method enables us to wind a coil directly on the inner surface of and outer cylinder and eliminates the bobbin and banding. An additional advantage is the increased capability of cooling due to the better thermal contact of the coil to outer cylinder on which a helium cooling tube is welded before coil winding.

The method has been developed since a year ago. Several test winding have been made in order to establish the winding technique. The winding of the main solenoid is going to complete this autumn.

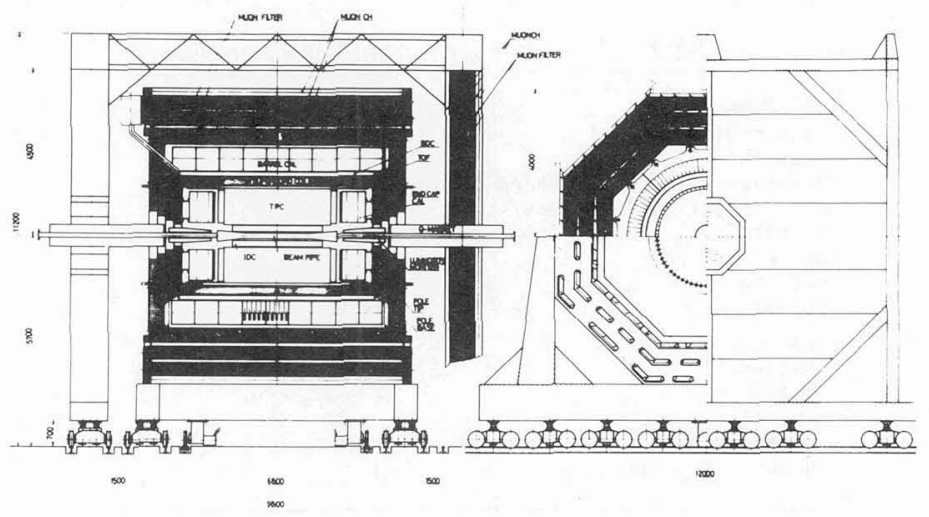

Fig. 1 Cross sections of the TOPAZ detector 


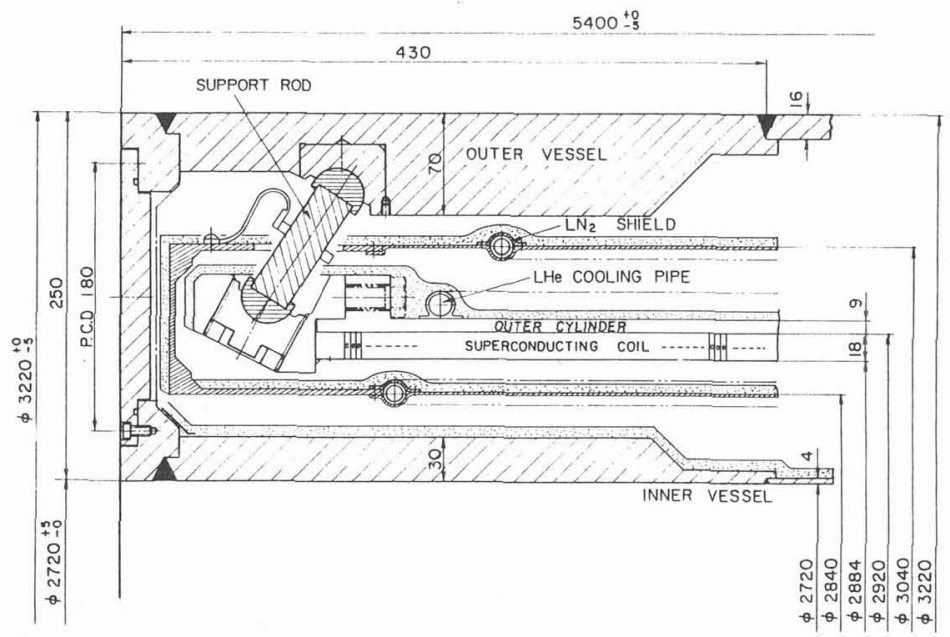

Eig. 2 Cross section at the end of the TOPAZ solenoid

\section{II - THE TOPAZ SOLENOID}

A schematic cross section at the end of the TOPAZ solenoid is shown in Fig. 2. The pure-aluminum stabilized superconductor is wound on the inner surface of the outer cylinder made of high strength aluminum alloy (A2219-T85). The electrical

insulation thickness between the coil and cylinder is expected to be less than $1 \mathrm{~mm}$, by using the internal winding method.

The design parameters of the TOPAZ solenoid are shown in Table 1. In the design process, the safety condition was carefully considered in order to protect the solenoid from quenching and burning out when it occurs and releasing the stored energy of $19 \mathrm{MJ}$. The safety condition we have considered are as follows:

1) The maximum operating current is chosen to be the half of the critical current at $B=2.4$ Tesla and $T=4.2 \mathrm{~K}$.

2) The coil temperature should be less than $5 \mathrm{~K}$ at normal operation.

3) The temperature of the coil in case of a quench should be kept below about $80 \mathrm{~K}$.

4) The voltage across the coil should be less than $500 \mathrm{~V}$, when the power supply is switched off because of a quench.

After the parameters were optimized each other, the total radiation thickness including the cryostat was estimated to be $0.71 \mathrm{x}_{0}$.

\begin{tabular}{ll} 
Table 1 Main parameters of the TOPAZ solenoid \\
\hline Coil Dimensions & $2884 \mathrm{~mm}$ \\
Inner diameter & $5100 \mathrm{~mm}$ \\
Length & 1.2 Tesla max. \\
Magnetic Field (with return yoke) & $0.71 \mathrm{Xo}$ \\
Total radiation Thickness & $3630 \mathrm{~A}$ \\
Current & $1340 \mathrm{Turns}$ \\
Number of Turns & $3 \mathrm{H}$ \\
Inductance & $19 \mathrm{MJ}$ \\
Stored Energy & \\
Conductor & $\mathrm{Nb}-\mathrm{Ti} / \mathrm{Cu} / \mathrm{Al}(99.999 \%)$ \\
Material & $1: 1: 20$ \\
Ratio & 22000 \\
RRR (Al) & $12.4 \mathrm{~km}$ \\
Length & 3
\end{tabular}


III - INTERNAL WINDING AND MODEL COILS

Figure 3 shows a schematic layout of the internal winding process for the TOPAZ solenoid.

At first the conductor insulated with B stage epoxy glass type is wound on the outer surface of a temporary mandrel and then preformed so as to have almost same curvature than that of the outer cylinder. The temporary winding is put into the outer cylinder. Then the winding on the inner surface of the cylinder is done by putting compression stress along the conductor ( $\varphi$ direction) so that the coil is pressed onto the surface. Axial and radial compression force are also applied simultaneously to the coil. To eliminate local voids and to get reliable thermal contact, wet epoxy resin is slightly painted on the inner surface of the outer cylinder which is insulated with the lamination of GFRP and KAPTON sheets. Finally, the coil is cured with the axial and radial compression at the temperature of $150^{\circ} \mathrm{C}$.

In order to establish the winding technique a full-size model $(2.9 \mathrm{~m} \times 5 \mathrm{~m})$ coil was wound with the dummy conductor where $\mathrm{Nb}-\mathrm{Ti} / \mathrm{Cu}$ matrix was replaced with $\mathrm{Fe}$ wire. In test winding process, many parameters such as compression stress, winding speed, quantity of the wet epoxy and etc. Figure 4 shows the view of the coil wound with the internal winding method.

After the curing process, the test coil was cut and observed. Figure 5 shows cross sections of the full size test coil. The void fraction at the layer of epoxy resin between the coil and outer cylinder is negligible and the averaged thickness of the ground-insulation (epoxy resin and GFRP-KAPTON lamination) was about $1 \mathrm{~mm}$. Mechanical properties at the boundary between the coil and ground-insulation were also measured after thermal eycles between room temperature and LN2 temperature. The sharing strength was above $2 \mathrm{kgf} / \mathrm{mm}^{2}$. It is enough acceptable from the view points of supporting for electromagnetic force and thermal stress.

A small size model solenoid was also wound with the same superconductor than that of the main solenoid. The differences of the parameters from that of the main solenoid are listed up in Table 2. It was cooled down below $4.8 \mathrm{~K}$ and was excited up to 5530 A which corresponds to 1.57 Tesla with out iron yoke. Detailed results of the test for the small model coil will be reported elsewhere.
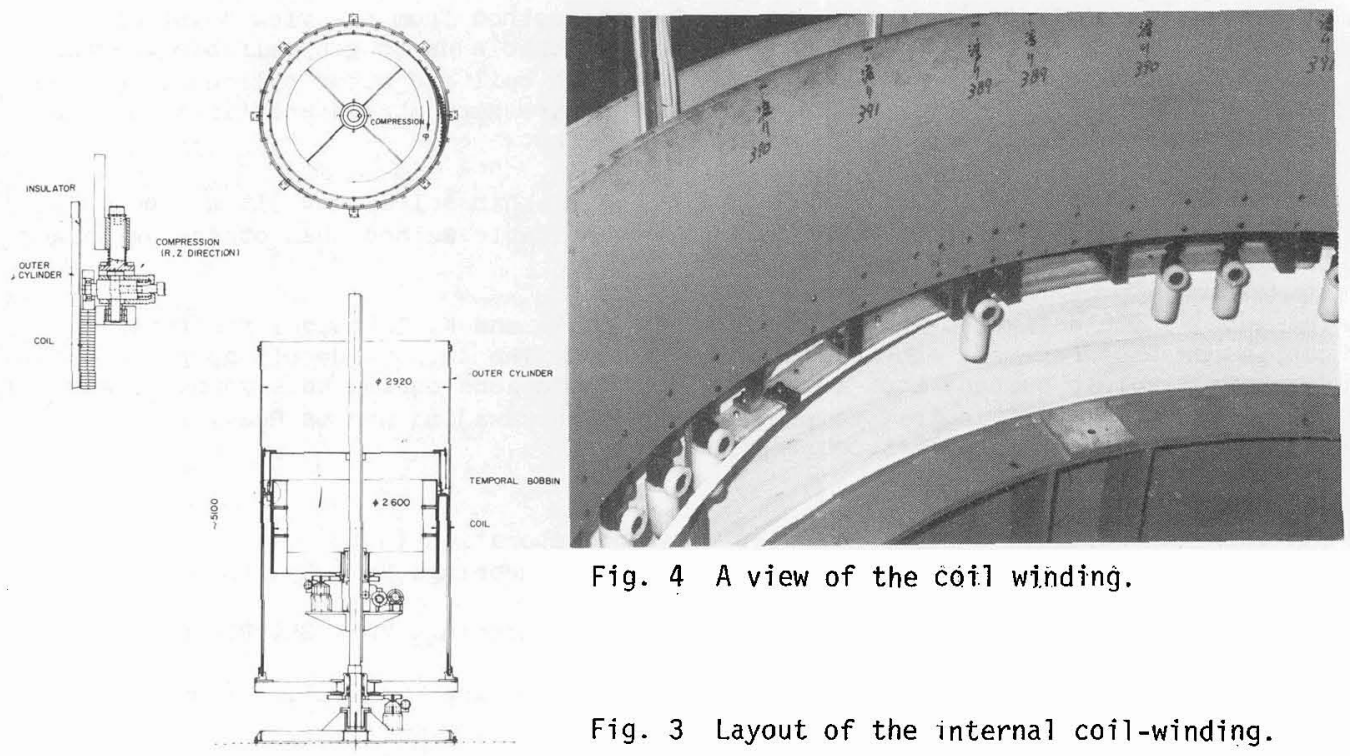

Fig. 4 A view of the coil winding.

Fig. 3 Layout of the internal coil-winding. 


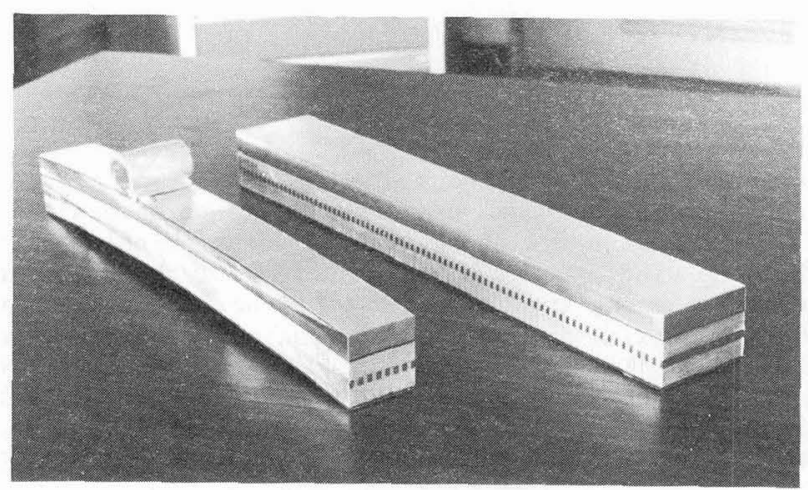

Fig. 5 Cross sections of the full size model coil

Table 2 Differences of the parameters of the small size

\begin{tabular}{|c|c|c|}
\hline Parameters & main solenoid & smal1 size model \\
\hline $\begin{array}{l}\text { COIL. } \\
\text { Outer diameter } \\
\text { Length }\end{array}$ & $\begin{array}{l}2.9 \mathrm{~m} \\
5.1 \mathrm{~m}\end{array}$ & $\begin{array}{l}0.58 \mathrm{~m} \\
0.9 \mathrm{~m}\end{array}$ \\
\hline $\begin{array}{l}\text { OUTER CYLINDER } \\
\text { Thickness }\end{array}$ & 9 ตกn & $8 \mathrm{~mm}$ \\
\hline $\begin{array}{l}\text { COOLING TUBE } \\
\text { Pitch between } \\
\text { parallel paths } \\
\text { Inner diameter }\end{array}$ & $\begin{array}{l}\text { v } 450 \text { min } \\
18 \text { milin }\end{array}$ & $\begin{array}{l}2600 \mathrm{~mm} \\
15 \mathrm{~mm}\end{array}$ \\
\hline
\end{tabular}

\section{IV - CONCLUSION}

The internal winding technique for thin solenoids has been established. Advantages of the internal winding are: (i) to be adequate method from the view point of supporting the electromagnetic force and (ii) to enable us to get reliable thermal and mechanical contact at the boundary between the coil and outer cylinder, because of less epoxy resin layer and well controlled compression stress and (iii) to have reliable fabrication process with no critical paths.

The internal winding method is adequate for larger thin solenoids. It may be sure that the internal winding is more adequate and reliable method than others at larger thin solenoids.

The authors would like to thank Professors S. Ozaki and K. Takahashi for their continuous encouragement and helpful discussions. The authors deeply appreciate Furukawa Electric Company Ltd. for valuable cooperations during this word. Thank are also due to Fuji Electric Company Ltd. and Ishikawajima-Harima Heavy Industry Company Ltd. for their expert cooperations.

\section{REFERENCES}

[1]. TRISTAN proposal, TRISTAN-EXP-002, TOPAZ collaboration (1983).

[2] Deportes (H) et al., Advances in Cryogenic Engineering, Vol. 25, Plenum Press, New York (1980), P.175.

[3] Green (M.A.) et al., Advances in Cryogenic Engineering, V01. 25, Plenum Press, New York (1980), P.194.

[4] Andrews. (D) et al., Advances in Cryogenic Engineering, Vol. 27, Plenum Press, New York (1981), P.143. 